\title{
Influence of Study Strategies on Performance of Business Education Students in Financial Accounting in Federal Universities in Nigeria
}

\author{
Umar, Rahmat Talatu (Mrs.) ${ }^{1}$, Professor M.M Aliyu ${ }^{2}$ \\ ${ }^{1,2}$ Department of Vocational \& Technical Education, Faculty of Education, Ahmadu Bello University, Zaria, \\ Nigeria
}

\begin{abstract}
The study was carried out to determine the Influence of study strategies (surface and deep study strategies) on Performance of Business Education Students in Financial Accounting in Federal Universities in Nigeria. The objective was to identify the differences in performance of business education students that adopted surface strategy and those that adopted deep study strategy in learning Financial Accounting. The population of the study was two hundred and eighty-one Financial Accounting students of the ten Federal Universities in Nigeria offering Business Education. Eighty students from the three first generation universities namely: Ahmadu Bello University, Zaria, University of Benin, Benin City and University of Nigeria, Nsukka were used as sample for the study. Revised Study Process Questionnaire (R-SPQ-2F) and Financial Accounting Evaluation Test (FAET) made of post-tests 1 and 2 were administered to the sampled students. The study adopted repeated measure experimental designs often referred to as within-subjects design. Descriptive statistic was used in answering the research questions, while the t-test was employed in testing the null hypothesis at 0.05 level of significance. The result revealed that study strategies had significant influence on performance of business education students in Financial Accounting. The results also showed that business education students that adopted deep strategy performed significantly better than those that adopted surface strategy. It was concluded that Business Education students performance could be because of the peculiar difference in their study strategy, their way of approaching tasks and possibly the skills and methods they use in solving problems. Any students who ignores these features is likely to have problem in learning Financial Accounting. It was recommended that lecturers should assist students to perform well in Financial Accounting by discouraging them from adopting surface strategy to learning. They should encourage students to adopt a deep approach, and inculcate analytical and critical thinking skills in the students in order to make them acquire the problem solving skills.
\end{abstract}

Keywords: Business Education Students, Financial Accounting, Study Strategy

\section{Introduction}

Active learning is a pedagogical approach in which students do not passively acquired knowledge, but instead are actively involved and engage in the learning process. Advocates of active learning suggest that it benefits students by promoting greater interest in the subject material enhancing intrinsic learning satisfaction, increasing understanding and retention of course material, developing the desire and ability to become lifelong learners and improving communication interpersonal, problem solving, analytical thinking and critical thinking. All learners manifest certain preferred learning strategy which is also referred to students' study strategy or approaches to learning. Study strategies can be defined as behaviours, steps, operations or technique employed by learners to facilitate the acquisition, storage retrieval and use of information (Oxford, 1990). Every student uses different strategy in his/her studying. It is the most widely used frame work for understanding how students go about learning in higher education (Tight, 2003; Ramburuth and Mladenovic, 2004). It is specifically concerned with discovering why some students learn better than others (Mcranni, Barbara, and Willis, 2009). According to Dujkora (2002), study strategies are specific actions taken by learners to make learning easier, faster, and more transferable to new situations. It is also perceived as particular form of observable behaviour employed by the learner (Dujkova, 2002). The two common approaches to learning are surface and deep processing. There are several techniques that are used in classifying students into surface or deep study strategy adopted in learning. One of the most notable techniques is Revised Study Process Questionnaire (R-SPQ-2F) (Tight, 2003). According to Entwistle and MaCune (2004), a student that adopts a deep approach to learning is identified with intention to understand, intrinsic motivation, use of evidence, critical thinking and relating ideas to already known concept and principles. This leads to understanding and long term retention of concepts so that they can be used for problem solving in unfamiliar contexts. On the other hand, student who adopts surface study strategies is identified with intention to reproduce, take a narrow view and concentrate on detail, stick closely to the course requirement, extrinsic motivation and literal memorization. Surface strategy leads to 
superficial retention of material for examinations and does not promote understanding or long term retention of knowledge and information.

In learning of Accounting, these two study strategies can be exhibited by students, which influence the learning processes and eventually affect the academic performance of learners. According to Ibrahim (2011) academic performance is what students achieve in their studies and how they cope with or accomplish different learning tasks given to them by their teachers. How students process information and approach a learning task will eventually influence the quality of the outcome.Students are required to possess and develop problemsolving skills for lifelong learning in Financial Accounting. The knowledge of Business Education students' attitude towards study strategies explain which learner learns better under what conditions, and which learner need additional support and assistance to be successful in learning. Financial Accounting is a course that is offered by business education students because of its importance to business education programme. According to Asaolu (2002), Financial Accounting is the process of recording, classifying, selecting, measuring, interpreting, summarizing and reporting financial data of an organisation to the users for objective assessment and decision-making. A basic knowledge of Financial Accounting equips students with the knowledge of keeping adequate records of financial transaction and a good analysis of business liquidity and profitability (Azih,2010).Identifying factors that explain which students perform better and are attracted to the discipline of accounting is of world-wide interest. It is against this background that the study investigated the impact of study strategies on performance of business education students in Financial Accounting in Nigerian Federal Universities with a view to ascertaining the influence of each of the variables (Surface Study Strategy and Deep Study Strategy) on the performance of students in Financial Accounting.

\section{Statement of Problem}

The increasing level of poor performance of students in financial accounting calls for need to ascertain a studying method that will improve the achievement of students in Financial Accounting in higher institution. Drennan and Rhode (2010) reported that generally performance of students in Accounting has not been impressive in higher institution. The performances of Business Education students in Financial Accounting in Ahmadu Bello University, Zaria for the period 2008 - 2011 affirm this observation. For instance, in 2008/2009 session, 40\% constituted students that passed within the range of credit and above. The 2009/2010 session result showed that only $30 \%$ of the students were within the credit range. There was further decline in the 2010/2011 session. The result showed that only $25 \%$ of Financial Accounting students passed within the credit level and above. One of the probable causes may be attributed to the nature of the study strategy adopted by the students in learning Financial Accounting. Hence, investigating the situation becomes imperative. Most of the students offering Financial Accounting consider it extremely difficult to master due to probably the pattern of study strategy adopted by them during learning process, and as a result this affects their ability to perform well.

\section{Purpose of study}

The major purpose of the study was to ascertain the influence of study strategy on the performance of business education students in Financial Accounting in federal universities in Nigeria.

Specifically, the study sought to:

1. classify business education students learning Financial Accounting in Federal Universities in Nigeria into those that adopt surface study strategy and deep study strategy using Revised Study Process Questionnaire (R-SPQ-2F).

2. examine the extent to which study strategies adopted by Business Education students influence their academic performance in Financial Accounting in Federal Universities in Nigeria

\subsection{Research questions:}

The study was guided by the following research questions:

1. To what extent can business education students adopt surface or deep study strategy in learning Financial Accounting in Federal Universities in Nigeria?

2. To what extent do study strategies adopted by business education students influence their academic performance in Financial Accounting in Federal Universities in Nigeria?

\subsection{Hypotheses}

The following null hypothesis which was tested at an alpha level of 0.05 guided the study:

There is no significant difference between the influence of surface and deep study strategies adopted by Business Education students in their academic performance in Financial Accounting. 


\section{Methodology}

The study utilised primary data and the instruments used for the data collection are questionnaire (SPQ) and Financial Accounting Evaluation Test (FAET). The original Study Process Questionnaire (SPQ) was developed by Biggs in 1987. The Revised Study Process Questionnaire (R-SPQ-2F) was modified in 2001 by Biggs, Kember, and Leung. It consists of twenty (20) items to determine the attitudes of students towards their studies and way of studying which eventually categorizes students into two study strategy used by them. Respondents decides the degree to which each item is true of him/her using a four-point categorization rating scale ranging from 'Always true of me' (4), 'Sometimes true of me' (3), 'Rarely true of me' (2) and 'Never true of me' (1). The respondents were asked to tick the appropriate point relevant to the subject. There are 10 items each for deep and surface strategy. The scores of the 10 items were added together for each strategy, and whichever is greater indicates the strategy the student uses. And FAET was to test students' knowledge in Financial Accounting. FAET consists of two tests: post-test 1 and post-test 2.

The study adopted the repeated measure experimental designs often referred to as within-subjects design. The population for this study was made up of all the Financial Accounting students in Business Education programs with Accounting option in the ten (10) Federal universities in Nigeria where the programmes were offered. The total population of the study was two hundred and eighty one (281) Business Education students. The sample comprised of eighty (80) Financial Accounting students in Business Education with Accounting option from Ahmadu Bello University, Zaria, University of Benin, Benin City and University of Nigeria, Nsukka. These institutions were chosen as samples because of their peculiar characteristics in term of long years of establishment and teaching experience. These universities have been running Business Education for over 30 years. Over these years, they have improved or modified the programme such that all other universities that subsequently started their own Business Education emulated them. Twelve (12) weeks were used to collect data in the three selected Federal universities. The first phase of the experiment was the administration of original Study Process Questionnaire (SPQ). The second phase of the experiment was the teaching of Financial Accounting. There was total five hours contact period for the teaching before the first post-test. The second and third contact hours of the first week were used to introduce the students to Partnership Account, while the second week contact hours were used to continue teaching students Partnership Final Account and some adjustments. At this stage post-test I of the Financial Accounting Evaluation Test was administered. The third week first contact hour period was used to teach the students how to prepare Profit and Loss Appropriation Account. The last two contact hours in the third week were used for introduction of Goodwill Account on admission of new partner and some practical questions were worked in the class. The whole fourth week was used to teach revaluation account. Each lesson was built on the last one. Thereafter, the researcher administered the second post-test of Financial Accounting Evaluation Test (FAET). Both the two post-tests were marked using their prepared marking schemes. In order to test the null hypothesis, t-test statistics was used at 0.05 level of significance.Mean and standard deviation were used to answer the research questions

\section{Data Presentation and Analysis}

The results of the investigation were presented according to the research questions and the hypothesis Research Question One : To what extent can business education students adopt surface or deep study strategy in learning Financial Accounting in Federal Universities in Nigeria?

Table 1: Frequency distribution of students into Surface study strategy and Deep Study Strategy

\begin{tabular}{ccc}
\hline Variable & N & Percentage \\
\hline SS & 62 & 77.5 \\
DS & 18 & 22.5 \\
\hline Total & 80 & 100 \\
\hline
\end{tabular}

\section{Source: Field Study 2013}

Sixty two (62) students equivalent to seventy seven and half percent (77.5\%) business education students adopted surface study strategy. Eighteen (18) students, equivalent to twenty two and half percent (22.5\%), adopted deep study strategy in learning Financial Accounting, as revealed in Table 1. This indicated that majority $(77.5 \%)$ of the students used surface study strategy.

Research Question Two: To what extent do study strategies adopted by business Education students influence their academic performance in Financial Accounting in Federal Universities in Nigeria? 
Table 2: Performance of Business Education Students based on surface and deep study Strategy adopted in learning Financial Accounting.

\begin{tabular}{cccc}
\hline Variable & N & Mean & Std. Deviation \\
\hline SS & 62 & 49.39 & 9.25 \\
DS & 18 & 58.61 & 8.05 \\
\hline
\end{tabular}

\section{Source: Data Output, 2013}

As indicated in Table 2, the mean achievement of the students that adopted Surface Study Strategy was 49.39, while that of those who adopted Deep Study Strategy was 58.61. Their standard deviation was 9.25 and 8.05 respectively. The difference between their mean achievements was very marginal and their standard deviation shows variance in their individual achievement. It is seen that students that adopted deep study perform better than the students that adopted surface study strategy in learning Financial Accounting

\subsection{Testing of Hypothesis}

Null Hypothesis : There is no significant difference in the influence of surface and deep study strategies adopted by business education students on their academic performance in Financial Accounting in Federal Universities Nigeria.

Table 3: Test of Difference in Performance between Students that adopted surface study strategy and deep study strategy

\begin{tabular}{lccccccc}
\hline Variable & $\mathbf{N}$ & Mean & SD & Df & t-test & P & Decision \\
\hline SS & 62 & 49.39 & 9.25 & & & & \\
& & & & 78 & -3.827 & .000 & Reject $\mathrm{H}_{\mathrm{o}} 2$ \\
DS & 18 & 58.61 & 8.05 & & & & \\
\hline
\end{tabular}

\section{Source: Data Output, 2013}

The analysis in Table 3 revealed that the $\mathrm{P}$ value was 0.000 . The t-calculated is -3.827 . Since the $\mathrm{P}$ value 0.000 was less than alpha value 0.05 , the null hypothesis was rejected. This is because students who adopted deep study strategy performed significantly better than students who adopted surface study strategy. The analysis also validates the result in Table 3. This means that there was enough reason to accept the difference that existed in the performance of those students that adopted surface study strategy and those that adopted deep study strategy.

\section{Discussions of Results}

The finding revealed that business education student who adopted deep study strategy to learning performed significantly better than those who adopted surface study strategy. This finding agreed with the findings of Biggs (1998), Haggis (2003) and Ramsdem (2003) who all concluded that deep study strategy approach to learning was important because students who used such an approach tended to earn higher grades and retained, intergrade and transfer information at higher rate. On the contrary, Davidson (2002) early reported that no significant relationship was found between influence of the use of deep study approach and surface study approach of students on performance of questions that were complex or examination results, but prior academic achievement, cumulative grade point average and motivation served as indicator of students' performance.

\section{Conclusion and Recommendation}

The result of the study established that students who adopted deep study strategy on the other hand performed significantly better in Financial Accounting than students who adopted surface study strategy. This could be because of the peculiar difference in their learning strategy, their way of approaching tasks and possibly the skills and methods they use in solving problems. Any student who ignores these features is likely to have problem in learning Financial Accounting. It is thus recommended that Accounting educators should assist students to perform well in Financial Accounting by discouraging them from adopting surface strategy to learning. They should encourage students to adopt a deep approach, and inculcate analytical and critical thinking skills in the students in order to make them acquire the problem solving skills. 


\section{References}

[1] Oxford, R.L. (1990). Language Learning Strategies: What every teacher should know. New York Newbury House/Harper and Row.

[2] Tight, M. (2003) Researching Higher Education. Maiden Lead, Berkshine, United Kingdom: McGraw Hill.

[3] Ramburuth, R. And Mlladenovice, R. (2004). Exploring the Relationship Between Students Orientations To Learning, The Structure Of Students' Learning Outc Publiched date 04. Feb 2014omes and Subsequent Academic Performance In Accounting Education. An International Journal of Accounting Education. 13(4), 507-527.

[4] Maranni, B., Barbara, F., and Pauline Willis (2009). An Inter-Institutional Exploration of the Learning Approaches of Students Studying Accounting. International Journal of Teaching and Learning in Higher Education, 20 (2), 156-168.

[5] Dujkora, B.B (2002). Individual Learning Styles and Strategies. Unpublished Msc. Thesis submitted to the post graduate school, University of Pardubice. Gzech Republic.

[6] Entwistle, N., and McCune, V. (2004). The Conceptual Bases of Study Strategy Inventories in Higher Education. Educational Psychology Review, 16, 325-346.

[7] Ibrahim, S. (2011). Impact of Accounting Background, Gender and Motivation on Performance of Business Education Students in Introduction Accounting in Federal Universities in Nigeria. An unpublished Doctorate Dissertation presented to the School of Post Graduate Studies, Ahmadu Bello University, Zaria.

[8] Asaolu, A. (2002). Modern Book-Keeping and Accounts Ibadan: Calabeks Publishers.

[9] Azih, N. (2010), Reducing the Global Economic Crisis in Nigeria: An Imperative for Accounting Education Graduate. Journal of Business Educational Researcher and Development, 1(2), 14-19.

[10] Drennan, L.G. and Rohde, F.H. (2010). Determinants of Performance in Advanced Undergraduate Management Accounting: An Empirical Investigation. Journal of Accounting and Finance, 42 (1), 27-40.

[11] Biggs, J. (1998). Assessment and classroom learning: A role for formative assessment? Assessment in Education: Principles, Policy and Practice, 5(1), 103-110.

[12] Haggis, T. (2003). constructing images of ourselves? A critical investigation into "approaches to learning" research in higher education. British educational research journal, 29 (1), 89-104.

[13] Ramsden, P. (2003). Learning to teach in higher education, $2^{\text {nd }}$ ed., London; Taylor and Francis, Inc.

[14] Davidson, R. (2002). Relationship of Study Approach and Exam Performance. Journal of Accounting Education 20(1), 29-44 